\title{
A Case of Contested Sovereignty: Explaining Ethnic Conflict in the Former Yugoslav Republic of Macedonia, 1991-2002
}

\author{
Tatiana P. Rizova \\ Department of Government Christopher, Newport University \\ 1 University Pl. Newport News, VA 23606, USA \\ Tel: 1-757-594-7971_E-mail: tatiana.rizova@cnu.edu
}

Received: June 20, 2011

Accepted: August 7, $2011 \quad$ Published: December 1, 2011

doi:10.5539/res.v3n2p73

URL: http://dx.doi.org/10.5539/res.v3n2p73

\begin{abstract}
In this paper, I explore why ethnic minorities engage in violence after gaining significant concessions from a ruling majority group. I use the case of the Former Yugoslav Republic of Macedonia because it allows me to evaluate the complex interaction of domestic and international causes in the emergence of ethnic violence. Instrumentalism and Lake and Rothchild's 'strategic dilemma' approach provide important insights in explaining violence in Macedonia. I complement these two theoretical approaches with an analysis of the strategic setting in the Balkans prior to the eruption of violence in Macedonia. I argue that Macedonian and ethnic Albanian leaders took advantage of the external challenges to Macedonia's sovereignty to mobilize their respective constituencies. The two groups' elites helped radicalize inter-group perceptions, which incited ethnic violence.
\end{abstract}

Keywords: Albanians, Ethnic conflict, Instrumentalism, Macedonia, Strategic dilemma

\section{Introduction}

The Former Yugoslav Republic of Macedonia (Note 1) (FYROM) is a tiny land-locked country where multiple ethnic groups vie for access to scarce political and economic resources.(Note 2) Why did the number of hostile encounters between ethnic Albanians and the Macedonian Slavs in Macedonia increase between 1991 and 2002, given that the Albanian minority's situation progressively improved?

Using the case of Macedonia, I analyze the emergence of ethnic violence at a time of economic and political improvement for an ethnic minority. The analysis presented here is rooted in two theoretical approaches instrumentalism and Lake and Rothchild's 'strategic dilemma' approach. I complement the insights gleaned from these analytical frameworks with an enquiry into Macedonia's regional environment, for it is hardly possible to fully explain ethnic conflict in Macedonia without considering the actions and political statements of Bulgarian, Serbian, Albanian, and Greek political elites. I argue that Macedonian and ethnic Albanian leaders capitalized on the external challenges to Macedonia's sovereignty to mobilize their respective constituents' support. This grassroots mobilization helped radicalize the two groups' political views and resulted in ethnic violence. Leaders such as Ljubčo Georgievski, who served as prime minister between 1998 and 2002, built political support around the idea that Macedonia's neighbors were a constant external threat to its sovereignty, while ethnic Albanians were presented as an internal threat to Macedonian territorial integrity. The Macedonian ethnic majority succumbed to those beliefs, which were only perpetuated by their virtual lack of contact with the Albanian community. (Note 3) Animosity rose and street violence, perpetrated by radical ethnic Albanians, ensued.

International relations scholars have traditionally been interested in understanding why ethnic conflict emerges and how ethnic unrest could be prevented or stopped. Few have explored the causes of ethnic conflict intensification, the rapid and intentional mobilization of ethnic violence to achieve political goals. (Note 4) Macedonia is a particularly interesting case study of ethnic conflict intensification that could help us understand how a low-intensity low-violence conflict spirals into a high-intensity high-violence one. Balkan history scholars have engaged in numerous arguments on the nascence of inter-ethnic conflict between the Albanians and Macedonians. (Note 5) The timeline presented by a Macedonian source traces the beginning of the conflict to the 1990s, when more than 2,000 ethnic Albanians protested in the city of Tetovo against the Macedonian majority's 
discrimination. (Note 6) Another source claims that the grievances of the ethnic Albanians date back to the 1980s.

Since 1981 many Albanians have been dismissed from their jobs by the Macedonian authorities. The army, the police, the judiciary and the economy have largely been dominated by Macedonians and they have generally decided who is to get jobs and licences. A large portion of the Albanian population was forced to seek work abroad since there have not been enough job opportunities in the FYROM. (Note 7)

I shall leave the issue of historical accuracy to experts on Balkan history. What is important, however, is that while tension did not commence in the post-independence era, the conflict did intensify after independence - a period in which the ethnic Albanians secured quite a few substantial political victories. (Note 8)

In December 1990, the first free multiparty elections were held in Macedonia since 1938. In the elections, the ethnic Albanian Party for Democratic Prosperity (PDP) won 25 out of 120 seats in the Macedonian National Assembly. (Note 9) The high degree of minority political participation Macedonia achieved was unprecedented in other parts of Yugoslavia. In September 1992, the first coalition government including PDP representatives was formed. In May 1998, the Albanian representative Arben Xhaferi "admitted that the ethnic Albanians in Macedonia are better off than those of any other Balkan country." (Note 10)

A New Republic article elaborates on some of the more significant achievements of the ethnic Albanians since 1993.

In 1993 ethnic Albanians held just 3 percent of jobs in the public sector; today the number exceeds 10 percent. Tens of thousands of Albanian schoolchildren are now educated in their own language, and an Albanian-language university has been established in Tetovo. There are 64 Albanian-language newspapers and magazines, scores of radio stations, and four hours per day of Albanian-language programming on the second state TV channel; a third, all-Albanian-language channel is in the planning stages. Three of the country's top seven generals are ethnic Albanian, along with five of 15 governmental ministers. Albanian mayors now represent 26 of Macedonia's 123 cities and towns. (Note 11)

Macedonia is a case that allows careful study of the interplay between domestic and international factors in causing violence. Located in the heart of the Balkans, Macedonia is a country whose external legitimacy has been frequently challenged by all of its neighbors - Bulgaria, the former Yugoslavia, Albania, and Greece. As a multi-ethnic society composed of two large ethnic groups, the predominantly Muslim ethnic Albanians and Christian Orthodox Macedonian Slavs, Macedonia's internal legitimacy has been contested by the ethnic Albanian constituents. The contestation of Macedonia's internal and external legitimacy has contributed to the intensification of conflict since the break-up of Yugoslavia under Milošević. This contestation engendered fears within the ethnic groups and created ideal conditions for the growth and spread of ultranationalist sentiments and parties in the country. Polling evidence indicates that for a significant period of time Macedonia's constituents subscribed to radical ideas, which resulted in an electoral victory for an ultranationalist party and the election of a xenophobic prime minister in 1998. (Note 12)

I explore the connection between the intense ethnic conflict in Macedonia and the 1999 events in Kosovo. (Note 13) One cannot treat the exacerbation of ethnic relations in Kosovo and Macedonia as isolated cases. They are linked by more than mere geopolitical ties. Arguably, the sympathy and political and military support of Western diplomats for the Albanian cause in Kosovo emboldened ethnic Albanians in Macedonia to demand political inclusion and expansion of their cultural and educational rights, and they sometimes sought to have their demands met through violent means. Had the United States and member states of the Organization for Security and Cooperation in Europe (OSCE) turned a cold shoulder to the Kosovo Albanians in 1999, inter-ethnic relations in Macedonia would have followed a different path. Unrest would still have fermented but the likelihood of violence would have been lower. Most of the violence in Macedonia was instigated by members of the rebel National Liberation Army (NLA), purportedly an extension of the Kosovo Liberation Army (KLA). Both KLA and NLA were notorious for their violent tactics, which helped sow fears among Serbs and Macedonians alike. (Note 14)

Despite their political differences, the Macedonian government and ethnic Albanian leaders reached an agreement on language rights, non-discrimination, and cultural freedom. The issue of educational rights was thorny, but definitely not an irreconcilable one. The controversial Tetovo University officially opened its doors with the blessing of the government in October 2001. Albanian representatives won quite a few political victories, yet violence erupted. Friedman takes stock of the concessions Albanians had secured in the area of language and cultural rights long before the hostilities of 2001. "In 1989, only Turkish and Albanian were represented on Macedonian public television: each had 130 minutes a week. By 2000, the figures for 
minority-language programming on national public television (MTV2) were 400 minutes for Albanian (...) Of 57 private local TV licenses given out in 1998 (after the passing of the Communications Act of 1997), 21 were for stations using minority languages, and of 80 private radio licenses, 26 had all or most programming in minority languages." (Note 15)

\section{Theories of Ethnic Conflict: Primordialism, Instrumentalism and the Strategic Dilemma}

International relations scholars have crafted theories of the causes of ethnic conflict and the factors that affect the probability of escalation and diffusion. This section will discuss the three most prominent theoretical approaches that can also be applied to the analysis of ethnic conflict intensification - primordialism, instrumentalism, and the strategic dilemma approach.

\subsection{Primordialism}

Primordialists emphasize the role of mistrust and enmity between ethnic groups as the underlying cause of ethnic disharmony. Mistrust, however, should not be treated as a "natural" condition, independent of the rhetoric and actions of group leaders, as primordialists might claim. Rather, mistrust could be engendered through government policies. Fearon articulates the primordialist interpretation of ethnic conflict in former Communist countries:

These people, the Xs and Ys, have hated and warred against each other for centuries; this is their natural condition. While strong, Communist domination kept them from killing each other, but ultimately the 'pot' boiled over (or it boiled over when the lid was removed). (Note 16)

Primordialist theorists see ethnic conflict as a natural consequence of inter-ethnic differences. Disagreement, and hence conflict, arise from incompatible preferences that are often the cause of violence. As many scholars have pointed out, primordialist explanations are inadequate because they cannot account for interethnic cooperation. If ethnic animosity is a function of the differences among groups, then why are most societies not in a state of constant warfare? Animosity as a permanent feature of ethnic interactions in a given society cannot account for changes in the intensity of conflict.

\subsection{Instrumentalism}

Instrumentalists envision ethnicity as an important political tool of control and domination. Political leaders seek to advance their material or non-material aspirations by placing ethnicity at the forefront of their political agendas. Instrumentalism is an important analytical framework because it demonstrates the existence of a crucial connection between the élite and the grassroots level of politics. Nevertheless, critics of instrumentalism argue that ethnicity cannot and should not be treated as a set of attributes, which could be easily manipulated by decision-makers.

In a similar vein, Paul Gagnon argues that "violent conflict is provoked by elites in order to create a domestic political context where ethnicity is the only politically relevant entity." (Note 17) The quintessential elements of domestic politics are the framing of ideas, the verbal expression of political values and judgments, and the exposition of political arguments, emphasizes Gagnon. They shape the outcome of political contestation that groups play out in the political arena. Gagnon explores the political mobilization of the Serbian majority against all other minor or major groups within the confines of Yugoslavia in the 1980s and early 1990s. He concludes that political élites in Yugoslavia helped portray the Serbian majority as the victim of "genocide" in Kosovo. (Note 18) This victimization would later on conveniently justify the violent action of Serbian authorities against the ethnic Albanian minority in the province of Kosovo.

The argument presented here is embedded in the instrumentalist framework because evidence suggests that political élites used ethnicity as a tool of advancing their political agendas. NLA rebels were framed as terrorists by the Macedonian government to demonize the ethnic Albanian community and affect the Macedonians' perceptions of the Albanian minority.

Constructivists treat ethnicity as a socially constructed phenomenon. Rather than being the product of individuals, ethnicity is a product of social systems. According to constructivists, "it is the social system that breeds violent conflict, not individuals, and it is the socially constructed nature of ethnicity that can cause conflicts, once begun, to spin rapidly out of control." (Note 19) Rothchild and Groth have argued that ethnicity has pathological dimensions that suffuse ethnic groups' reality with a sense of loss and uncertainty about their fate. (Note 20) Three factors contribute to the pathology of ethnicity: modernization, changes in the distribution of wealth, and the fragility of political institutions. Modernization is associated with the displacement of traditional values and the institution of novel ones. Changes in the distribution of wealth brought about by economic downturns, for example, cause severe competition for increasingly scarce resources. 
It seems that changes in the distribution of wealth in Macedonia could be partly responsible for the intensification of conflict. Just like the other former Communist countries, Macedonia experienced a sharp economic downturn after the demise of Communism. In 1996 the U.N. Secretary-General reported that industrial production in the country declined by almost 50 percent, whereas half of the work force remained unemployed as a result of the economic slump. (Note 21) Not surprisingly, ethnic tensions increased during that period. If political institutions are inefficient in responding to economic changes, they will be unable to cushion the negative effects of economic shocks. A combination of modernization, economic slumps and inefficient institutions is a recipe for ethnic disaster. Enemy stereotypes easily capture the imagination of individuals in times of political, economic, and social turmoil because of the uncertainty that inevitably accompanies them.

\subsection{Strategic dilemma}

David Lake and Donald Rothchild explore the causes and management of ethnic conflict. Ethnic conflict, in their theoretical framework, is the outcome of three strategic dilemmas: information failure, a lack of credible commitment on behalf of the parties involved or third party mediators, and the presence of incentives to use force preemptively. These security dilemmas are magnified by the minority and majority group's "collective fear of the future." (Note 22) Groups compete for scarce economic and political resources such as "property rights, jobs, scholarships, educational admissions, language rights, government contracts, and development allocations." (Note 23)

The situation in Macedonia corroborates many of Lake and Rothchild's insights. First, both groups have had numerous incentives to keep or misrepresent private information about their relative coercive capacity. Second, there was a lack of credible commitment to peace on behalf of either group. Third, the logistically weaker group - the ethnic Albanians - may have used force preemptively by launching guerrilla campaigns against Macedonian government forces. Lake and Rothchild's approach, however, does not tell us the whole story about ethnic conflict.

Groups are uncertain about multiple future outcomes. First, conflict between non-state actors occurs in an atmosphere of extreme uncertainty about future resource allocations. The minority group is uncertain whether today's promise about language and education rights or non-discrimination will be honored by future political leaders. The majority is uncertain whether allowing education in the minority group's native language will lead to demands for further concessions. Second, groups are uncertain about the ethnic power balance that will prevail five, ten or twenty years since the beginning of conflict. Third, the future trustworthiness of today's politicians, let alone tomorrow's, is impossible to evaluate.

Uncertainty about these three future outcomes aggravates ethnic conflict and complicates its management. Because of this uncertainty, minority groups are likely to place maximum demands at the bargaining table rather than increase their demands incrementally. The expectations of minority groups are set high from the outset of bargaining. Minority groups will opt for institutional guarantees in the form of ethnic federalism, partition, or self-governance, which would surpass the biases and predilections of individual politicians. Minority groups will also push for constitutional protection of their status as culturally unique groups. A relatively recent case of successful constitutional engineering is the 1988 Brazilian constitution, which recognized indigenous peoples as culturally and ethnically distinct groups. (Note 24)

Fearon and Laitin criticize the constructivist approach for its failure to establish a solid empirical link between the social construction of ethnic identity and ethnic violence. In turn, the two scholars suggest two possible scenarios of how the construction of ethnic identity alters the ethnic balance and causes conflict. First, political leaders are capable of changing the "social content associated with being a member of each [ethnic] category." (Note 25) Second, extremists attempt to "sharply delineate identity boundaries that everyday interaction and moderates' political agendas threaten to blur." (Note 26)

Seeking an explanation of the ethnic conflict in Yugoslavia, Oberschall attempts to bridge the fundamental insights of instrumentalism and constructivism. His argument hinges on the idea that ethnic frames and perceptions of the 'other' are important in determining decisions to engage in violence or not. Two frames dominated the consciousness of Yugoslavs, he argues. The frame of ethnic cooperation and peace dominated Serbs' mentality in normal times. The antithesis of the cooperative frame, the crisis frame, was awakened by political élites in Yugoslavia. Elite and media propaganda helped suppress the normal frame and contributed to the escalation of fear and conflict in the country.

Oberschall's argument that elites manipulate and activate different ethnic frames to attain their goals is certainly plausible. However, the analysis only discusses how the dominant group (Christian Orthodox Serbs) perceived 
the minority Muslim group, while ignoring the minorities' perceptions of the ethnic majority. It is unclear why the subversive crisis frame lay dormant for such a long period of time and became revived at a time of crisis.

Bargaining theorists present ethnic conflict as an outcome of strategic interactions between (or amongst) ethnic groups. Several dilemmas arise as a result of the strategic situations in which ethnic groups find themselves. In most inter-ethnic conflicts, the state becomes the locus of group distributional struggles. Even if representatives of the ethnic groups sit at the bargaining table, conflict might still ensue as a result of information failures. During bargaining, groups tend not to reveal their true preferences and information about their military, organizational, and leadership capacity. Strategic situations also cause problems of credible commitment. "Ethnic conflicts arise because groups cannot credibly commit themselves to uphold mutually beneficial agreements they might reach." (Note 27)

Armed conflict is a costly enterprise. Therefore, ethnic groups should be able to find a peaceful resolution that leaves them better off than armed conflict. Why is peace hard to reach then? Fearon argues that it is difficult for a majority to commit to moderate demands in a new state because "at that point its bargaining power will have increased due to the consolidation of police and army capabilities." (Note 28) Hence a peaceful agreement might be sabotaged due to the lack of credible commitment on behalf of the majority. The argument, however, rests on the assumption that while a majority reorganizes and mobilizes control in a new state, minorities fail to do so. Agreements do not fail only because of majorities. The success of a peaceful agreement between a majority and a minority depends on their expectations of the ethnic power balance that will prevail in the near and distant future.

Leonard Binder introduces the idea of "ethnic contract" which is a "specification of "rights and responsibilities, political privileges, and access to resources of each group." (Note 29) In this model, violence arises because of incompatible policy preferences and commitments that lack credibility.

Barry Posen puts forward the idea of the security dilemma at the domestic level of analysis. Under conditions of anarchy, each group is uncertain about the intentions of other groups. Thus each group will have the incentive to improve its military capacity to develop a worst-case scenario survival strategy. Military and organizational preparation becomes a self-fulfilling prophecy and leads to the outburst and escalation of conflict. (Note 30) Strategic bargaining models are by design élite-based. Moreover, they treat ethnic groups as unitary actors, and they hardly ever are unitary.

\section{Conflict Intensity in the Former Yugoslav Republic of Macedonia between 1991 and 2002}

\subsection{Low-intensity low-violence conflict, 1991-1999}

Since Macedonia's successful secession from the Yugoslav federation in 1991, radical representatives of the ethnic Albanians have threatened to secede from Macedonia. In February 1990, over 2000 ethnic Albanians protested in the district of Tetovo against discrimination by Macedonians. At the end of the same year, the first free elections were held in Macedonia. (Note 31) The ethnic Albanian Party for Democratic Prosperity (PDP) won its first 25 seats in the 120-seat Macedonian Parliament. Just two years later, conflict surfaced in Bit Pazar an ethnic Albanian neighborhood in Skopje. Police detained 87 people during the unrest. At the beginning of 1994, an ethnic Albanian political leader - Mithad Emini - was arrested with nine other ethnic Albanians on allegations of separatist activities. (Note 32)

One of the most contentious issues was the opening of an Albanian-language university in Tetovo in 1994. Some of the events surrounding the controversial institution were several walkouts by ethnic Albanian members of Parliament, numerous student protests, and the arrest of the Dean of the Tetovo University in 1995. The only reported fatal incident was that of a man killed in clashes between 1,500 ethnic Albanians and Macedonian police outside the premises of the university on February 17, 1995. The political activity of the ethnic Albanians was vibrant during the 1990s. Much of the political activity was bottom-up, an expression of popular disapproval of official Macedonian policies toward the ethnic Albanian population. There was also significant élite activity on behalf of parliamentarians and government officials throughout the 1990s.

\subsection{High-intensity high-violence conflict, 1999-2002}

The number of fatalities rose dramatically at the beginning of 2001 when Albanian guerrillas, members of the National Liberation Army (NLA), (Note 33) initiated series of attacks on Macedonian police forces. High-intensity high-violence conflict in Macedonia coincided with at least three developments in Macedonia. First, there was a large influx of ethnic Albanian refugees from Kosovo in 1998 and 1999, which altered the demographics of Macedonia. The number of ethnic Albanians in Macedonia is still a contested issue. Albanians claim that they constitute about $40 \%$ of the population, whereas official government statistics estimate that the 
Albanians make up approximately $23 \%$ of the population. Second, members of the Kosovo Liberation Army (KLA) fled into Macedonia and gave birth to the National Liberation Army (NLA), which has been responsible for a number of clashes with authorities. Members of KLA may have been emboldened by NATO and UN support of the Albanian cause in the Kosovo crisis. Third, ethnic conflict started in the midst of a nation-building project in Macedonia. (Note 34) It has been extremely hard for the Macedonian government to deal with the internal and external challenges to its legitimacy simultaneously. A comprehensive discussion of ethnic violence necessitates an analysis of the political agents directly or indirectly responsible for triggering hostilities.

\section{Political Agents and Their Agendas}

\subsection{Prime Minister Ljubčo Georgievski}

Georgievski has been involved in the country's politics since the first free elections in 1990. He was one of the founders of a Macedonian nationalist party - the Internal Macedonian Revolutionary Organization - Democratic Party for Macedonian National Unity (VMRO-DPMNE). This party was a vocal participant in the pro-independence movement in Macedonia. Its political objectives included Macedonian independence, withdrawal of the Yugoslav National Army, an independent currency, and international recognition of Macedonian sovereignty. "The party's message was that Macedonia was only for the Macedonians, which produced widespread resentment among the republic's ethnic minorities." (Note 35)

Georgievski openly condemned the actions of the National Liberation Army. In a May 2001 interview he "called the rebels "Talibans" trained and armed in Kosovo by Western democracies as part of their war against Slobodan Milosevic. He scoffed at the notion that they were fighting for equal rights." (Note 36) During the interview, the Prime Minister also listed the reforms executed by Macedonian governments in the 1990s, urging his Western audience to "name one single state in Europe or North America where minorities have such huge rights as Albanians in Macedonia." (Note 37)

\subsection{President Boris Trajkovski}

President Trajkovski, a former Methodist minister, was definitely more moderate than Prime Minister Georgievski. Trajkovski succeeded Kiro Gligorov after an electoral victory in November 1999 secured with the support of ethnic Albanians. (Note 38) The Macedonian President was one of the proponents of a "partial demilitarisation" plan, which included an amnesty clause for the NLA rebels, and evacuation plans for the civilian population. (Note 39) This peace deal also contained a provision for disarmament of the NLA and promised equal rights for ethnic Albanians. "The plan has not been rejected by Albanian political parties, but it falls short of addressing rebel demands for direct involvement in the talks and a place for their soldiers in a reconstituted national security force." (Note 40) According to its constitution, Macedonia is a parliamentary democracy in which the Prime Minister is the actual political leader and the President is a figurehead. Even though Georgievski enjoys more popularity among Macedonian Slavs, the moderate Trajkovski has been the preferred negotiation partner by Western diplomats. (Note 41)

\subsection{Ethninc Albanian leader Arben Xhaferi}

A former member of PDP, Arben Xhaferi has been involved in Macedonian politics ever since the first democratic elections were held in 1990. In 1994, the PDP held a national congress, during which the party split into two factions. Xhaferi became the head of the radical faction of the party. During the Kosovo crisis of 1998, Xhaferi made a public statement regarding the situation of the Albanians in Kosovo and Macedonia:

Nano [the Albanian Prime Minister] seems to labor under the illusion that idyllic inter-ethnic relations prevail in Macedonia at a time when the Albanian people are suffering a tragedy in Kosova; when the Macedonian government fails to support the idea of Kosova's independence; when there are Albanian political prisoners; when Tetovo university is not recognized; when the official use of the Albanian language is forbidden, and the Macedonian press tries every day to portray the Albanians as terrorists and elements that destabilize the Balkans. (Note 42)

Xhaferi is also actively involved in the larger project for recognition of ethnic Albanians as "equal partners in the country" and "proportional representation for Albanians in the police and other state bodies." (Note 43)

\subsection{Former NLA leader Ali Ahmeti}

Ahmeti used to be a leader of the rebel National Liberation Army that placed politics back on the streets. His name appears on an executive order issued by President Bush earlier in 2001 prohibiting Balkan insurgents to enter the United States. (Note 44) His appearance on the Macedonian political stage in 2001 was quite opportune. Ahmeti was in Kosovo in 1998 and derived much of his inspiration from the 'victory' of the Kosovo Albanians 
in the Kosovo civil conflict. One of the lessons he learnt in Kosovo was that successful recognition of the ethnic Albanians in Macedonia would require Western support. The second lesson was that armed struggle could achieve much more in the short run than political bargaining. Violence pays off. It attracts the attention of Western diplomats. It is, indeed, the weapon of the weak and disadvantaged. "Ahmeti and the NLA deliberately chose violence. The lesson they learned from Kosovo was: if you play your cards right, a little well-calculated violence achieves what years of nonviolent politics had not. Which once again, it did." (Note 45) Ahmeti did not endorse ethnic federalism as an institutional mechanism of curbing the conflict between Macedonians and Albanians. When prompted to comment on the viability of administrative autonomy, he quipped "in a country with just two million people and 25,000 square kilometers?" (Note 46) After receiving presidential amnesty for participating in acts of terror as an NLA leader, he traded his weapon and rebel uniform for a political post and a smart suit. He founded an ethnic Albanian party - the Democratic Union for Integration (DUI) - and was elected to the Macedonian parliament in the elections held on September 15, 2002. His party garnered between 60 and 70 percent of the ethnic Albanian vote, making it more popular than the already established Party for Democratic Prosperity. Ahmeti's party won 16 out of 120 seats in the Macedonian parliament, whereas PDP won a mere 7 seats. Nevertheless, the proportional representation system guaranteed ethnic Albanians political participation and will force the winner - the new electoral coalition Together for Macedonia - to form a coalition government with the ethnic Albanian parties. (Note 47) Ahmeti demanded that ethnic Albanian representatives take the Ministry of the Interior and the Ministry of Defense after the 2001 parliamentary elections(Note 48). Leaders of the Social Democratic Party (SDP) warned the winning electoral league that granting two key ministerial seats to the Albanians could be deleterious to the fragile ethnic peace. (Note 49) Ahmeti, on the other hand, considered receiving the two posts an important element of furthering the integration of the Albanians into Macedonian society. DUI's unequivocal association with a defunct terrorist organization was unacceptable to the majority of the Macedonian population. Such a reaction was not surprising given that DUI's structure, financing, and membership were kept secret (Note 50).

\subsection{National Liberation Army}

In principle, NLA's demands did not diverge from those of ethnic Albanian politicians. They included language and education rights, constitutional change, more representation in the Macedonian bureaucracy, the courts, and the police. One might ask why the NLA took to cities and streets instead of patiently awaiting the democratic process to take its course. It appears that the NLA 'represented' those ethnic Albanians who had little patience for the snail's pace of the reforms. For the most part, Western diplomats considered the demands of ethnic Albanians reasonable. Devolution was indeed part of the political agenda of the NLA and Albanian politicians(Note 51). Many Macedonian Slavs, however, feared that devolution might lead the country down the path of secession.

\subsection{Coalition government}

Macedonia has had a multi-ethnic coalition government since the 1990s. Upon the advice of former U. S. Secretary of State Colin Powell a grand coalition was formed as hostilities in the country increased in May 2001. The coalition comprised five major parties, among which were the two leading ethnic Albanian parties, in an effort to enhance political dialog among the ethnic rivals. (Note 52) The main goal of the coalition was to craft a workable peace accord that would resolve the conflict. One of the chief provisions of the plan was disarmament of the National Liberation Army observed by NATO troops. Disarmament took place in September 2001. Approximately 4,000 pieces of weapons, mostly nonfunctional, were collected from the rebel army. It is very unlikely that all weapons of the NLA were collected. Macedonian Slavs raised serious doubts about the success of the peace plan and disarmament. (Note 53)

The commitment to disarmament was qualitative rather than quantitative. No minimum number of weapons to be collected was specified at the outset. The crucial problem with this part of the peace plan was the impossibility to observe compliance. Perhaps the fears of the Macedonian Slavs were justified. Before disarmament was supposed to begin, NLA fighters blew up an Orthodox church and a monastery in Tetovo. (Note 54)

\section{The political landscape in the Former Yugoslav Republic of Macedonia}

Macedonian party leaders have inevitably had to address the issues of Macedonian territorial autonomy and Albanian rights in their party programs. From its very conception, the Internal Revolutionary Organization Democratic Party for Macedonian National Unity (VMRO-DPMNE) has been advancing an ultra-nationalist agenda. Its program states that its goal is the "complete spiritual, political, economic and ethnic uniting of the partitioned Macedonian people and a state in the future United Balkans!" (Note 55) Members of the Albanian Party for Democratic Prosperity demanded an internationally monitored census, inclusion of the Albanian 
constituents in decision-making, more extensive television programming in the Albanian language, and opening a Teacher's School to train teachers in Albanian. (Note 56)

Ethnic Albanians should not be treated as a monolithic group. Political tensions rooted in distinctions over the future of the ethnic Albanians abound. Supporters of PDP - once the mainstay of ethnic Albanians in the political arena - witnessed these political divisions firsthand.

Tensions have continued and have been mirrored within the PDP, the main ethnic Albanian party, which is divided between those who favour autonomy along the lines of the controversial 'Ilirid' declaration, those supporting closer links with Albania, and a third bloc opposed to any notion of autonomy but seeking a civic rather than an ethnic state of Macedonia. (Note 57)

The final split within the Party for Democratic Prosperity occurred in February 1994, when "the old PDP leadership, including the Albanian coalition government ministers, walked out of the final congress and formed a separate party named 'the Party of Continuity." (Note 58) The split allowed the accommodation of various interests that were underrepresented by PDP. The event, however, also led to the fragmentation of the ethnic Albanian political élite and allowed the radicalization of some Albanians' political views. The emergence of the Union for Democratic Integration further indicates the existence of divisions among the ethnic Albanians. DUI has most certainly allowed the representation of radical interests in the Macedonian parliament.

During the years preceding the intensification of ethnic conflict in Macedonia, political sentiments ran amok. Both Macedonians' and Albanians' political views had been radicalized. (Note 59) Young Albanians showed their support for the Democratic Party of Albania (DPA) and young Macedonians supported the nationalist Internal Macedonian Revolutionary Organization, which resulted in the election of the two radical parties to the Macedonian Parliament in 1998. (Note 60) Support for radical parties resulted in cabinet fragmentation and government gridlock. The slowdown in the political process tested the patience of the Albanian minority to the detriment of attempts for peaceful cooperation between the two groups.

\section{The Grassroots: Macedonians and Albanians in FYROM}

The ethnic Albanians, by far the largest minority in the area of former Yugoslav Macedonia, lived and continue to live in compact settlements in the west of the republic bordering on Albania, the north-west bordering on the predominantly Albanian province of Kosovo, and in Skopje where they make up over 14 per cent of the population. They are a majority of the population in many western areas, notably the districts of Tetovo (about 113,000 Albanians to 38,000 Macedonians), Gostivar (63,000 to 18,000), Kicevo (23,000 to 21,000), and Debar $(10,000$ to 2,500$)$. (Note 61 )

The distinctions between the Macedonian and Albanian people were emphasized by the 1974 Constitution passed under the Ranković government. This constitution embodied a three-tier system of national rights. The Yugoslav Federation was officially comprised of six nations, several nationalities and other ethnic groups. The six 'nations of Yugoslavia' included the Croats, Macedonians, Montenegrins, Muslims, Serbs and Slovenes. The second tier included the Hungarian, Italian, and Albanian nationalities. The third tier was composed of 'ethnic communities,' such as Czechs, Roma, Austrians, and Slovaks. The 1974 Constitution introduced a clear hierarchy which instituted the dominance of the Macedonian nation vis-à-vis the Albanian nationality. (Note 62)

Ranković's manifestly anti-Albanian and anti-Muslim policies have marked the history of the Albanian community. Even though it has been difficult to document these policies, there is evidence that Ranković signed agreements with the Turkish government at the time "in an official attempt to ethnically purify Slav-held lands. As official statistics suggest, this policy of the "repatriation" of ethnic Turks really constituted expulsions of large numbers of Albanians (purposefully labeled Turks) for a period of over 15 years." (Note 63)

One of the complaints, which attracted the support of most ethnic Albanians, is underrepresentation at all levels of governance. In June 1993 PDP leader Halili remarked that "there were no courts presided over by Albanians, no ethnic Albanians in the Macedonian Army General Staff or in the Interior and Foreign Ministries, and no region where Albanians predominate which had place- or street-names in Albanian." (Note 64)

The ethno-linguistic and religious demands of the Albanians form an integral part of their call for cementing the cultural heritage of the Albanian population in the region. In Yugoslavia, the Serbian language and educational system were used as important tools of assimilation into the Yugoslav Federation. The availability of tertiary education in Albanian has been one of the important demands of the ethnic Albanians. Prior to the legal opening of the Tetovo University, many Albanians pursued higher education degrees at Priština University in Kosovo. "Assimilation through Serbian education was the policy, and the predominantly Muslim religious schools, 
known as 'Turkish' schools, were seen as useful in keeping the Albanians in a state of ignorance until this could be achieved." (Note 65)

Oftentimes Macedonians criticize Albanians for refusing to speak the Macedonian language. The Albanians have responded that "there is no fundamental reason why Macedonian should be the language of state, challenges a sacred tenet of nationalism - the existence of a single dominant medium of communication." (Note 66)

The Kosovo and Macedonian Albanians sustained close ties throughout the decades of Serbian domination (Note 67). Poulton suggests that the 1981 protests in Kosovo were followed by unrest instigated by Albanians elsewhere on the Balkans. He argues that "the growth of Albanian nationalism in SR Macedonia was seen as possibly fatal, not only to the territorial integrity of the republic but even to the very existence of the Macedonian nation." (Note 68) The Albanian community was seen as a threat to the territorial integrity of the republic and the Macedonian government saw fit to subordinate and suppress it. The government introduced administrative measures to curb the high birth rate of the Albanians: "among the measures were that families should pay for medical services for any children above the ideal number of two and that there would be no child allowance and possibly even a financial penalty for such extra children." (Note 69)

As fears of the Albanians intensified in the 1980s, the government scrutinized the interactions among the various ethnic groups residing in the republic. The paranoia of political leaders led them to suspect the Albanians of attempting to assimilate the Roma population. The Albanians were considered an important internal threat; their leaders were accused of leading an Albanianisation campaign among the local Roma. (Note 70)The mass exodus of Kosovo Albanian refugees to Macedonia in 1999 intensified the Macedonians' fears of the Albanians. "Macedonia, faced with the prospect of huge numbers of Albanian refugees entering the country, resorted in April 1999 to drastic measures like the forced overnight resettlement of 40,000 Kosovar refugees from a camp in Macedonia to Albania." (Note 71) This reaction is indicative of how palpable and acute the Albanians threat was.

The Albanians' political preferences regarding their community's position in Macedonia differ. Some have called for a federation, others are in favor of a two-nation state; a third group of radicals has even considered secession. (Note 72) The Macedonians' fear of the irredentist aspirations of the ethnic Albanians is not unfounded. The successful Macedonian secession of 1991 taught the Albanians that separation might be a viable option for their own community. The viability is augmented by the fact that the Albanians live in settlements concentrated in the Western part of the country.

In 1992 Albanians' aspirations were manifested in an illegal referendum which "demonstrated that 90\% supported independence; in 1994 they declared an autonomous republic "Illyrida" in the western part of the Republic." (Note 73) Former President Kiro Gligorov sent an early signal of his intolerance to all expressions of Albanian nationalism that challenge the legitimacy of the Macedonian state. When the Law on Flags (Note 74) was passed, the President commented unequivocally: "the move we made on flags was meant to draw a red line to show how far another state can go (Albania, Turkey, Serbia or any other state) in protecting the interests and rights of national minorities. We wanted to show when demands for rights turn into interference in a state's internal affairs." (Note 75)

Inter-ethnic dialogue was significantly hindered by the groups' lack of mutual understanding. The Albanians' and Macedonians' perceptions of the other have been dominated by stereotypes which have only perpetuated inter-ethnic prejudice. Ackermann has found that "each group perceives the other as more aggressive, although psychological tests have revealed traits of nonaggressiveness (Beska 1996a). Nevertheless, each group believes itself more peaceful than the other." (Note 76) Biljana Vankovska tells the story of two adjacent, yet isolated, communities: "Macedonians have most often lived next to one another but as two separate worlds where the elements dividing them have been emphasized more than the elements bringing them together (different ethnic origins, cultures, traditions, languages and religions)." (Note 77)

\section{The Balkan context: FYROM and its Neighbors}

Macedonia's neighboring countries are partly responsible for amplifying the fears of the Macedonian political leaders of foreign interest in Macedonian territory. The roots of these ambitions for territorial expansion can be traced back to Balkan history. In the 1920s, Bulgarian political leaders proposed the idea of a Balkan Federation. (Note 78)

The successors or survivors of Sandanski's Serres faction, led by Todor Panitsa, also favoured a Macedonia within a Balkan federation - a plan outlined by Dimov in a pamphlet of 1919 entitled 'Back to Autonomy' which called for a Macedonian republic modelled on the Swiss federation within a wider Balkan federal context. (Note 
79) Tito made extraordinary political efforts to stifle Serbian and Bulgarian ambitions to lay claim to Macedonian territory. He granted Macedonia the status of an independent republic to curb Serbian interests "especially because, in the first Yugoslav state, the Serbs had categorically referred to this territory as "Southern Serbia." (Note 80)

The Macedonian government has taken all opportunities to protect the republic from challenges to its external legitimacy. To demonstrate his belief that the Bulgarian and Macedonian languages are distinct, former Macedonian Prime Minister Crvenkovski used an interpreter in June 1993 when the Bulgarian Prime Minister Berov visited him in Skopje. (Note 81)

The Bulgarian President Zhelyu Zhelev was the first to recognize the Former Yugoslav Republic of Macedonia as a sovereign country. Despite this amicable gesture on behalf of the president, however, at the beginning of the post-totalitarian period in Bulgaria, several influential political leaders announced that "there was no 'Macedonian Question' and that Macedonians were Bulgarians." (Note 82)

The Internal Macedonian Revolutionary Organization (VMRO) played a critical role in disseminating the revolutionary idea of Macedonian unification at the end of the $19^{\text {th }}$ and beginning of the $20^{\text {th }}$ century. Macedonia and Bulgaria both have parties which have tried to resurrect the revolutionary agenda of VMRO. Naturally, however, VMRO's agenda has evolved throughout its two centuries of existence. The 1920s marked a turning point in the history of VMRO. Leaders of the Bulgarian VMRO gave mixed signals regarding the kinship between the Macedonians and the Bulgarians: "to the outside world VMRO portrayed Macedonians as part of the Bulgarian nation, while to Bulgarians it manifested a fierce autonomy bordering on independence." (Note 83) Certain facts attest to Bulgaria's friendly attitude toward the newly-fledged republic of Macedonia. Bulgaria was the first to recognize its status as a state. It did not concede to a division of Macedonia's territory with Greece, nor did it accept a similar proposal on behalf of Yugoslavia. (Note 84)

The tension between the Greek and the Macedonian governments escalated upon Macedonia's secession from the Yugoslav Federation. The cause of discord between the two governments was the name of the new republic. (Note 85) As Poulton notes, "the Greek authorities ever since the founding of the modern Greek state have consistently denied the existence of the Slav Macedonians as a separate people from the Greeks. Instead they have referred to them officially as Slavophone Greeks while the Bulgarians claimed them to be Bulgarians..."(Note 86)

\section{Terrorists or Freedom Fighters}

Framing is an important mobilization tool. It establishes a criterion of inclusion and exclusion. The members of the Kosovo Liberation Army were treated as freedom fighters and guerrillas whose liberation cause was just and admirable. Initially, the members of the NLA were given the same treatment. The perception and policy position of the United States changed after the conflict escalated as exhibited in several official policy statements. On April 20, 2001 Secretary of State Colin Powell expressed his support for the Macedonian cause by addressing the Macedonian authorities with these words:

You can be sure of American support for your efforts - political support, economic support, and military support. You are facing a challenge, which you must meet. That is to show to the rest of this region and to show to the world that people of different backgrounds, different ethnicities can come together in peace and find a way to resolve differences through political dialogue and a common commitment to a single state. (Note 87)

This statement was less partial than the one Colin Powell made at a meeting with President Boris Trajkovski on May 1, 2001:

I made a point to the President that we must not allow terrorists to derail political reconciliation. As long as we keep moving in this direction, we will dry up the support that terrorists might think they enjoy... And I expressed my condolence and the condolence of the American people to the families of the eight Macedonian soldiers who lost their lives as a result of this terrorist act. (Note 88)

For the first time, a U.S. government official made such references to the guerrillas of the NLA condemning their activities as acts of terrorism. This statement marked a critical point of re-framing of the ethnic Albanian militants as members of a terrorist movement. Re-framing has affected and will continue affecting the strategy of the Macedonian Slavs vis-à-vis the ethnic Albanians.

Mr. Léotard, French defense minister from 1993 to 1995, has expressed a caveat regarding the legal/illegal status of the NLA. 
The line between legal and regular and illegal and irregular forces becomes blurred on all sides when countries slide towards ethnic war. So, in the end, pledges not to "negotiate with terrorists," which NATO and the EU have repeatedly made with respect to Macedonia, may have to be broken. (Note 89)

And indeed, they were. President Trajkovski promised to pardon NLA fighters who voluntarily disarmed under NATO supervision. The amnesty, however, did not include guerrillas who were "indictable by the U.N. war crimes tribunal." (Note 90)

DPA leader Arben Xhaferi articulated the Albanians' position on the status of the NLA. In his view NLA members could not be treated as terrorists, for terrorists do not have political leaders, do not wear uniforms and do not have a political program. The emergence of NLA was a natural outcome of the dissatisfaction of the Albanian people with the Macedonian government, argued Xhaferi.

On June 11, 2001 the U.S. State Department issued a statement which condemned the "extremist actions of the so-called National Liberation Army." On June 27, 2001 President Bush issued an executive order restricting entry into the United States of Balkan extremists. Members of the NLA were blacklisted along with other extremist groups.

The activities of the NLA undoubtedly damaged the reputation of ethnic Albanians as a group. Many Macedonian Slavs consider all Albanians terrorists. The Macedonian Slavs have traditionally feared the pan-Albanian ambitions of the ethnic Albanian population. The emergence of the NLA reinforced the enemy stereotypes through which Albanians and Macedonians sought empowerment.

Beck has emphasized the importance of the enemy stereotype as a source of self-affirmation and self-identification vis-à-vis one's neighbors.

Enmity arouses enmity. Enemy stereotypes irritate, mark others off, insult, prepare for violence and generate angst until what they speak of actually happens. Neighbours, people of different languages and from different cultures, first become strangers and then enemies. Enemy stereotypes have the terrible power of being self-fulfilling, because they set in motion a mechanism of resistance and response which, in its anticipation of anxiety, only provides new nourishment for all sorts of anxiety. (Note 91)

Both ethnic Albanians and Macedonian Slavs have held stereotypes of each other. A team of six Bulgarian scholars conducted surveys of Albanians and Macedonians in the summer of 1999. The Macedonian respondents were particularly fearful and aggressive when approached with questions about the ethnic Albanians. (Note 92) Western media and foreign policy statements made by U.S. and West European policy-makers have been instrumental in shaping the perceptions of the majority and minority group of one another. Trust has definitely been a scarce commodity in Macedonia. Uncertainty about future allocations of political and economic resources aggravates the conflict even further and could deepen the animosity between the two ethnic groups.

\section{Conclusion}

While bargaining failure is not intrinsic to democracy, it is a highly likely outcome, particularly in plural societies where ethnicity is the dough of politics. Based on observations of the conflict in Macedonia, several conclusions could be drawn. First, the increase in the number of hostilities and deaths in Macedonia between 1999 and 2001 (prior to the Ohrid Agreement) does appear to be the product of NLA involvement in acts of violence. Second, Macedonian and ethnic Albanian leaders used the challenges the country faced abroad as a means of mobilizing their constituents at home. The electoral system allowed the inclusion of small radical parties in the political process and led to the fragmentation of the legislative process and decision-making in the Macedonian Parliament and governing coalitions. (Note 93) Third, ethnic disharmony occurred as a result of the internal and external challenges to Macedonia's sovereignty.

\section{References}

Ackermann, A. (2000). Making Peace Prevail: Preventing Violent Conflict in Macedonia. Syracuse, N.Y.: Syracuse University Press.

Adamson, K. and Jović, D. (2004). The Macedonian-Albanian Political Frontier: the Re-articulation of post-Yugoslav Ethnic Identities. Nations and Nationalism, 10 (3), 293-311. http://dx.doi.org/10.1111/j.1354-5078.2004.00168.x

"Albanians in Macedonia" Unrepresented Nations and Peoples Organization. [Online] Available: http://www.unpo.org/member/albans/albans.html (July 7, 2003)

Anastasijevic, D. (2001). Fall From Grace: Once a Rare Multiethnic Success Story, Macedonia Now Looks Like a Tinderbox. Time International, 157 (21). 
Beck, U. (1998). Democracy Without Enemies. Cambridge: Polity Press.

Purvis, A. (2001). Behind Rebel Lines: As NATO Vacillates Over Military Intervention in Macedonia, Ethnic Albanians Advance on the Capital. Time International, 157 (25).

Blumi, I. (1997). The Question of Identity, Diplomacy and Albanians in Macedonia: Has the Rain Come? International Journal of Albanian Studies, 1 (1), 32-56.

Brown, K. S. (2000). In the Realm of the Double-Headed Eagle: Parapolitics in Macedonia 1994-5. In J. Cowan (Ed.). Macedonia: the Politics of Identity and Difference. London: Pluto Press.

Brunnbauer, U. (2004). Fertility, Families, and Ethnic Conflict: Macedonians and Albanians in the Republic of Macedonia, 1944-2002. Nationalities Papers, 32 (3), 565-598. http://dx.doi.org/10.1080/0090599042000246406

Bulgarian Telegraph Agency, Albantsite v Makedonia iskat ministerstvata na otbranata i na vutreshnite raboti. [Online] Available: http://www.netinfo.bg/?tid=40\&oid=380409 (July 15, 2011).

Daskalovski, Z. (1999). A New Era: Macedonia's New President. Central European Review, 1 (1), [Online] Available: http://www.ce-review.org/99/22/daskalovski22.html

Eriksen, T. (1993). Ethnicity \& Nationalism: Anthropological Perpectives. London: Pluto Press.

Executive Order 13219, issued by President George W. Bush on June 27, 2001 [Online]. Available: http://www.treasury.gov/resource-center/sanctions/Documents/13219.pdf (July 15, 2011).

Fearon, J. and Laitin, D. (2000). Violence and the Social Construction of Ethnic Identity. International Organization, 54 (4), 845-877. http://dx.doi.org/10.1162/002081800551398

Fearon, J. (1995). Rationalist Explanations for War. International Organization, 49 (3), 379-414. http://dx.doi.org/10.1017/S0020818300033324

Fearon, J. (1998). Commitment Problems and the Spread of Ethnic Conflict. In D. Lake \& D. Rothchild (Eds.). The International Spread of Ethnic Conflict: Fear, Diffusion, and Escalation. Princeton, N.J.: Princeton University Press.

Friedman, V. A. (2006). Macedonia: Language Situation. In K. Brown (Editor-in-Chief), Encyclopedia of Language \& Linguistics, Second Edition, volume 7, pp. 354-356. Oxford: Elsevier.

Gagnon, V. P. Jr. (1994). Ethnic Nationalism and International Conflict: The Case of Serbia. International Security, 19 (3), 130-166. http://dx.doi.org/10.2307/2539081

Garton, A. T. (2001). Is There a Good Terrorist? The New York Review of Books.

Hammer, J. and Cirjaković, Z. (2001). Tetovo Dispatch: Borderlines. New Republic.

Heinrich, M. Macedonia Pardons 11 Guerrillas to Launch Amnesty. [Online]. Available: http://www.alb-net.com/amcc/ (July 15, 2011).

Hislope, R. (2004). Crime and Honor in a Weak State: Paramilitary Forces and Violence in Macedonia. Problems of Post-Communism, 51 (3), 18-26.

Holliday, G. (2004). From Ethnic Privileging to Power-Sharing: Ethnic Dominance and Democracy in Macedonia. In Smooha, S. and Jarve, P. The Fate of Ethnic Democracy in Post-communist Europe Budapest: Local Government and Public Service Reform Initiative and Open Society Institute.

Hope and Fear. The Economist June 30, 2001.

Info Regarding the Current Developments in Macedonia. [Online]. Available: http://www.macedonia.org/crisis/timeline.html (July 15, 2011).

Interview with Ljubčo Georgievski conducted July 3, 2001. [Online]. Available: http://www.euractiv.com/en/enlargement/ins-outs-interview-macedonian-prime-minister/article-110111 (July 14, 2011).

Jeffery, S. (2001). Crisis in Macedonia. [Online] Available: http://www.guardian.co.uk/macedonia/story/0,7369,506920,00.html, (July 15, 2011).

Joseph, E. (2005). Back to the Balkans. Foreign Affairs, 84 (1), 111-122. http://dx.doi.org/10.2307/2539070

Lake, D. and Rothchild, D. (1996). Containing Fear: The Origins and Management of Ethnic Conflict. International Security, 21 (2), 41-75. http://dx.doi.org/10.2307/20034211 
Macedonian Scientific Institute, Sofia. (1997). Memorandum Regarding the Language Dispute. [Online]. Available: http://www.kroraina.com/knigi/mpr/memorandum.html (July 15, 2011)

Mojzes, P. (2001). Into the Inferno? Christian Century, 118 (24).

Nikolov, S. (2002). Sajuz s Ahmeti shte reshi izborite v Makedonia. 168 chasa.

On a Knife-edge: Macedonia's Ethnic Fighting. The Economist June 2, 2001.

Papavizas, G. (2010). FYROM: Searching for a Name, and Problems with the Expropriation of History. Mediterranean Quarterly, 21 (3), 86-110. http://dx.doi.org/10.1215/10474552-2010-017

Pettifer, J. (1999). The New Macedonian Question. London: McMillan Press Ltd.

Political Parties in the Republic of Macedonia. [Onine]. Available: http://www.b-info.com/places/Macedonia/republic/partiesPDP.shtml (July 15, 2011).

Posen, B. (1993). The Security Dilemma and Ethnic Conflict. In M. Brown (Ed.). Ethnic Conflict and International Security. Princeton, N.J.: Princeton University Press.

Poulton, H. (2000). Who Are the Macedonians? Bloomington and Indianapolis: Indiana University Press. $\left(2^{\text {nd }}\right.$ ed.)

Ringdal, K., Simkus, A. and Listhaug, O. (2007). Disaggregating Public Opinion on the Ethnic Conflict in Macedonia. International Journal of Sociology, Fall 2007, 37 (3), 75-95. http://dx.doi.org/10.2753/IJS0020-7659370304

Rothchild, D. and Groth, A. (1995). Pathological Dimensions of Domestic and International Ethnicity. Political Science Quarterly, 110 (1), 69-82. http://dx.doi.org/10.2307/2152051

United Nations Preventive Deployment Force - Former Yugoslav Republic of Macedonia. [Online]. Available: http://www.un.org/Depts/DPKO/Missions/unpred_b.htm - ECONOMIC (July 15, 2011).

U. S. Statement on Macedonian Parties Coalition Agreement 051101. [Online]. Available: http://reliefweb.int/node/81417 (July 15, 2011).

Vankovska, B. (2001). Macedonia After the Kosovo War: The Way from the "Powder Keg" to the Oasis of Peace - and Back Again Transnational Foundation for Peace and Future Research [Online]. Available: http://www.transnational.org/forum/meet/Macedoniaafterwar.html (July 7, 2003).

Veroiatna pobeda za koalitsiata na Crvenkovski v Makedonia. Monitor, September 16, 2002.

Wilmer, F. (1993). The Indigenous Voice in World Politics: Since Time Immemorial. London: SAGE Publications.

Zhelyazkova, A. Macedonia and Kosovo After the Military Operations. [Online]. Available: http://www.omda.bg/imir/mk_after1.html (July 15, 2011).

\section{Notes}

Note 1. For simplicity, I will use Macedonia rather than FYROM.

Note 2. Eriksen (1993: 14) would most likely define the two groups as "ethnic groups in 'plural societies'." "The groups that make up a plural society, although they are compelled to participate in uniform political and economic systems, are regarded as (and regard themselves as) highly distinctive in other matters. In plural societies, secessionism is usually not an option and ethnicity tends to be articulated as group competition."

Note 3. Joseph, E. (2005). Back to the Balkans. Foreign Affairs, 84 (1), p. 116.

Note 4. Intensification is the increase in the number of hostilities and deaths as a result of violence. I use the term intensification to distinguish it from the terms escalation and diffusion used by Rothchild and Lake in The International Spread of Ethnic Conflict. Conflict diffusion occurs when violence in one state increases the probability of violence in another state. Escalation occurs when belligerents become engaged in a conflict abroad. See p. 23 in The International Spread of Ethnic Conflict: Fear, Diffusion, and Escalation. Princeton, N.J.: Princeton University Press, 1998.

Note 5. Ulf Brunnbauer, for example, argues that the two communities are torn apart by differences in "the structures of communal life, reproductive and economic behavior, and patterns of cultural reproduction." These differences were aggravated by the country's socialist experience. See Brunnbauer, U. (2004). Fertility, Families, and Ethnic Conflict: Macedonians and Albanians in the Republic of Macedonia, 1944-2002. Nationalities Papers, 32 (3), 565-598. Holliday asserts that Albanians' grievances are rooted in the systematic discrimination 
against them in the ethno-cultural and socio-economic arena. Holliday, G. (2004). From Ethnic Privileging to Power-Sharing: Ethnic Dominance and Democracy in Macedonia. In S. Smooha \& P. Jarve (Eds.) The Fate of Ethnic Democracy in Post-communist Europe. Budapest: Local Government and Public Service Reform Initiative and Open Society Institute, pp. 140-141.

Note 6. "Info Regarding the Current Developments in Macedonia" [Online] Available: http://www.macedonia.org/crisis/timeline.html. This information sheet is a historical timeline containing factual information provided by well-renowned European news agencies such as Reuters and the BBC and the Macedonian daily Dnevnik.

Note 7. "Albanians in Macedonia" Unrepresented Nations and Peoples Organization. [Online] Available: http://www.unpo.org/member/albans/albans.html

Note 8. Macedonia won independence from Yugoslavia in 1991.

Note 9. Timeline p. 1

Note 10. Ibid. p. 4

Note 11. Hammer, J. and Z. Cirjaković. "Tetovo Dispatch: Borderlines" New Republic April 30, 2001, p. 22.

Note 12. In spite of the nationalist agenda of its leader, IMRO-DPMNE formed a coalition government with the ethnic Albanian Democratic Party of Albanians under his leadership. The Democratic Party of Albanians was born out of a merger between the Party for Democratic Prosperity and the People's Democratic Party in 1997.

Note 13. Poulton, H. (2000). Who Are the Macedonians? Bloomington and Indianapolis: Indiana University Press, $\left(2^{\text {nd }}\right.$ ed.), p. 90.

Note 14. Former Prime Minister Georgievski claimed that there was definitely a link between the KLA and the NLA. "The main leaders are Macedonian Albanians that [sic] two years ago joined KLA structures. Now they are returning to Macedonia through Kosovo. Finally, Macedonia, in the last ten years, granted citizenship to 160,000 Albanians from Kosovo and south Serbia who fled the tortures of Milosevic. 90 percent of Macedonian Albanians who participate in these terrorist groups are these refugees from Yugoslavia." Interview with Ljubčo Georgievski conducted July 3, 2001, [Online] Available: http://www.euractiv.com/en/enlargement/ins-outs-interview-macedonian-prime-minister/article-110111

Accessed July 14, 2011. See also Hislope, R. (2004). Crime and Honor in a Weak State: Paramilitary Forces and Violence in Macedonia. Problems of Post-Communism, 51 (3), 18-26.

Note 15. Friedman, V. A. (2006). Macedonia: Language Situation. In K. Brown, (Editor-in-Chief) Encyclopedia of Language and Linguistics, ( $2^{\text {nd }}$ ed.), 7, Oxford: Elsevier, 354-356.

Note 16. Fearon, J. (1998). Commitment Problems and the Spread of Ethnic Conflict. In D. Lake \& D. Rothchild (Eds.). The International Spread of Ethnic Conflict: Fear, Diffusion, and Escalation. Princeton, N.J.: Princeton University Press.

Note 17. Gagnon, V. P. Jr. (1994). Ethnic Nationalism and International Conflict: The Case of Serbia. International Security, 19 (3), 130.

Note 18. The precise name of Kosovo was long the bone of contention between Serbs and ethnic Albanians, even before Kosovo announced its independence from Serbia. Serbs refer to it as Kosovo, whereas ethnic Albanians insist on calling it Kosova to emphasize its status as an independent republic.

Note 19. Lake, D. and D. Rothchild (Eds.). The International Spread of Ethnic Conflict: Fear, Diffusion, and Escalation. Princeton, N.J.: Princeton University Press, p. 6.

Note 20. Rothchild, D. and A. Groth. (1995). Pathological Dimensions of Domestic and International Ethnicity. Political Science Quarterly, 110 (1), 69-82.

Note 21. United Nations Preventive Deployment Force - Former Yugoslav Republic of Macedonia. [Online] Available: http://www.un.org/Depts/DPKO/Missions/unpred_b.htm - ECONOMIC

Note 22. Lake, D. and D. Rothchild. (1996). Containing Fear: The Origins and Management of Ethnic Conflict. International Security, 21 (2), p. 41.

Note 23. Ibid. p. 43

Note 24. Such constitutional changes have also occurred in Norway, the Philippines, New Zealand, and Canada. See Wilmer, F. (1993). The Indigenous Voice in World Politics: Since Time Immemorial. London: SAGE Publications, p. 156. 
Note 25. Fearon, J. and D. Laitin. (2000). Violence and the Social Construction of Ethnic Identity. International Organization, 54 (4), p. 865.

Note 26. Ibid., p. 865.

Note 27. Fearon, J. (1995). Rationalist Explanations for War. International Organization, 49 (3), 379-414.

Note 28. Fearon, J. (1998). Commitment Problems and the Spread of Ethnic Conflict. In D. Lake \& D. Rothchild (Eds.). The International Spread of Ethnic Conflict: Fear, Diffusion, and Escalation. Princeton, N.J.: Princeton University Press, p. 118.

Note 29. Lake, D. and D. Rothchild. (1998). p. 13

Note 30. Posen, B. (1993). The Security Dilemma and Ethnic Conflict. In M. Brown (Ed.). Ethnic Conflict and International Security. Princeton, N.J.: Princeton University Press.

Note 31. The district of Tetovo, located in Western Macedonia, has been a trouble spot ever since Macedonian independence. It is populated by a large number of ethnic Albanians.

Note 32. Timeline.

Note 33. The Albanian initials of the NLA are the same as these of the Kosovo Liberation Army (KLA) - UCK. The NLA was founded by members of the KLA, which disbanded after the Kosovo crisis.

Note 34. It is arguable that the project of nation-building could be facilitated by the fact that Macedonia's internal sovereignty has been challenged by a minority group. A contested nationhood strengthens a national identity. Macedonia's nationhood has also been contested by its neighbors. Macedonia's official name FYROM - is courtesy of the Greek government contestation of the name Macedonia. Bulgarians still consider the Macedonian language a dialect of the Bulgarian language.

Note 35. Ackermann, A. (2000). Making Peace Prevail: Preventing Violent Conflict in Macedonia. Syracuse, N.Y.: Syracuse University Press, p. 57.

Note 36. Anastasijevic, D. (2001). Fall From Grace: Once a Rare Multiethnic Success Story, Macedonia Now Looks Like a Tinderbox. Time International, 157 (21)

Note 37. Ibid.

Note 38. See Daskalovski, Z. (1999). A New Era: Macedonia’s New President. Central European Review, 1 (1). [Online] Available: http://www.ce-review.org/99/22/daskalovski22.html

Note 39. On a Knife-edge: Macedonia’s Ethnic Fighting. The Economist June 2, 2001, p. 3.

Note 40. Purvis, A. (2001). Behind Rebel Lines: As NATO Vacillates Over Military Intervention in Macedonia, Ethnic Albanians Advance on the Capital. Time International, 157 (25), p. 29.

Note 41. Mojzes, P. (2001). Into the Inferno? Christian Century, 118 (24), p. 14

Note 42. Timeline.

Note 43. Anastasijević, p. 28.

Note 44. Executive Order 13219, issued by President George W. Bush on June 27, 2001. [Online] Available: http://www.treasury.gov/resource-center/sanctions/Documents/13219.pdf Accessed July 15, 2011. Several members of the NLA including Ali Ahmeti were mentioned in the executive order. The order effectively blocks property of persons "who threaten international stabilization efforts in the Western Balkans." The executive order was extended by President Barack Obama on June 23, 2011.

Note 45. Garton Ash, T. (2001). Is There a Good Terrorist? The New York Review of Books, p. 32.

Note 46. Ibid. p. 31

Note 47. Together for Macedonia consists mainly of moderate parties.

Note 48. Bulgarian Telegraph Agency, Albantsite v Makedonia iskat ministerstvata na otbranata i na vutreshnite raboti. [Online] Available: http://www.netinfo.bg/?tid=40\&oid=380409 (July 15, 2011).

Note 49. Ibid.

Note 50. Nikolov, S. "Sajuz s Ahmeti shte reshi izborite v Makedonia” 168 chasa September 6-12, 2002 : p. 32.

Note 51. Ibid. 
Note 52. "U.S. Statement on Macedonian Parties Coalition Agreement 051101". [Online] Available: http://www.uspolicy.be/Issues/Balkans/mace051101.htm . The observers of the agreement condemned violence instigated by the Albanian extremist groups.

Note 53. A Guardian article revealed that disarmament operation "Essential Harvest" was received with a large dose of cynicism by the Macedonian government and people. "The main obstacle in the peace deal is mistrust," the article asserts. "The government claims that the rebels have ten times the 2,000 weapons that they admit to, which puts NATO in a difficult position since it must collect a figure that is acceptable to both sides if the operation is to succeed in rebuilding confidence and promoting peace." Jeffery, S. (2001). Crisis in Macedonia. [Online] Available: http://www.guardian.co.uk/macedonia/story/0,7369,506920,00.html, (July 15, 2011).

Note 54. Mojzes, p.14.

Note 55. Political Parties in the Republic of Macedonia. [Onine]. Available: http://www.b-info.com/places/Macedonia/republic/partiesPDP.shtml (July 15, 2011).

Note 56. Ibid.

Note 57. Poulton, p. 184

Note 58. Ibid. p. 196

Note 59. Ringdal, K., Simkus, A. and O. Listhaug. (2007). Disaggregating Public Opinion on the Ethnic Conflict in Macedonia. International Journal of Sociology, Fall 2007, 37 (3), 75-95.

Note 60. Ibid., p. 199

Note 61. Ibid., p. 125

Note 62. Adamson, K. and D. Jović. (2004). The Macedonian-Albanian Political Frontier: the Re-articulation of post-Yugoslav Ethnic Identities. Nations and Nationalism, 10 (3), 293-311.

Note 63. Blumi, I. (1997). The Question of Identity, Diplomacy and Albanians in Macedonia: Has the Rain Come? International Journal of Albanian Studies, 1 (1), 32-56.

Note 64. Poulton, p. 188

Note 65. Ibid., p. 91

Note 66. Brown, K. S. (2000). In the Realm of the Double-Headed Eagle: Parapolitics in Macedonia 1994-5. In J. Cowan (Ed.). Macedonia: the Politics of Identity and Difference. London: Pluto Press.

Note 67. Important distinctions exist within the Albanian community. There are at least two distinct Albanian groups - the Torbeshi (also known as pomaks in Bulgaria) and the Muslim Albanians or Turks. The Torbeshi, just like the Bulgarian pomaks, converted to Islam to take advantage of tax breaks extended to converts during Ottoman rule.

Note 68. Poulton, pp. 126-127

Note 69. Ibid., p. 128

Note 70. Ibid., p. 141

Note 71. Ibid., p. 200

Note 72. Brown, p. 129

Note 73. Vankovska, B. (2001). Macedonia After the Kosovo War: The Way from the "Powder Keg" to the Oasis of Peace - and Back Again Transnational Foundation for Peace and Future Research [Online]. Available: http://www.transnational.org/forum/meet/Macedoniaafterwar.html (July 7, 2003).

Note 74. The Law on Flags prohibited the use of foreign flags in public places.

Note 75. Pettifer, J. (1999). The New Macedonian Question London: McMillan Press Ltd.

Note 76. Ackermann, p. 64.

Note 77. Vankovska, p. 3.

Note 78. Poulton, p. 81

Note 79. Sandanski is one of the renowned historical figures claimed by both the Macedonians and the Bulgarians. He fought for the liberation of Pirin Macedonia from the Ottoman yoke; Dimitar Dimov was a Bulgarian revolutionary poet. 
Note 80. Ackermann, p. 55

Note 81. Poulton, p. 215

Note 82. Ibid., p. 151

Note 83. Ibid., p. 84

Note 84. Macedonian Scientific Institute, Sofia. (1997). Memorandum Regarding the Language Dispute. [Online]. Available: http://www.kroraina.com/knigi/mpr/memorandum.html (July 15, 2011)

Note 85. Greek politicians maintain that naming the country the Republic of Macedonia "implicitly invokes claims to the Greek part of the region of Macedonia, including its capital Thessaloniki." Papavizas, G. (2010). FYROM: Searching for a Name, and Problems with the Expropriation of History. Mediterranean Quarterly, 21 (3), 87.

Note 86 . Poulton, p. 85

Note 87 . Timeline, p. 8

Note 88. Ibid.

Note 89. "Hope and Fear” Economist June 30, 2001

Note 90. "Macedonia Pardons 11 Guerrillas to Launch Amnesty" by Mark Heinrich. [Online] Available: http://www.alb-net.com/amcc/

Note 91. Beck, U. (1998). Democracy Without Enemies. Cambridge: Polity Press, p. 144.

Note 92. An excerpt from the final report indicates how deeply the feelings of enmity run: "The [Macedonian] respondents reacted aggressively to our questions putting counter-questions: "Have you ever seen a Muslim with less than 5-8 children? And what about you, how many children have you got or have you any children at all?"; "How many Muslims are there in Bulgaria?", "They will soon sweep over you as well", "Do you have Albanians in your country?", "Oh, the Turks are something else, one can live with them...."; "What shall we do?" - "All the orthodox people in the Balkans should unite in one state in order to withstand the Albanians and the Muslims...", "It is maybe only a confederation with Bulgaria that could frighten these shipters..." Why did you give air passages to NATO but not to Russia?", "Macedonia will be small for them, they'll come to Bulgaria too". This fear, verging on neurosis explains the fact that not one Macedonian family invited refugees at their home and the refugees caused a new escalation of the xenophobic feelings among the Macedonians." The full text of the report - "Macedonia and Kosovo After the Military Operations" by Antonina Zhelyazkova. [Online] Available: http://www.omda.bg/imir/mk_after1.html.

Note 93. In the past, 85 of the 120 members were elected in single member districts (SMDs) while the rest of the seats were allocated through proportional representation (PR). As of 2002, after changes in the country's electoral law, all seats are allocated through PR. There is no legal threshold for participation in the parliamentary elections. "Veroiatna pobeda za koalitsiata na Crvenkovski v Makedonia" Monitor, September 16, 2002. 